Erratum

\title{
Erratum: Alvar-Beltrán, J. et al. Effect of Drought, Nitrogen Fertilization, Temperature and Photoperiodicity on Quinoa Plant Growth and Development in the Sahel. Agronomy 2019, 9, 607
}

\section{Agronomy Editorial Office}

MDPI, St. Alban-Anlage 66, 4052 Basel, Switzerland; agronomy@mdpi.com

Received: 10 December 2019; Accepted: 19 December 2019; Published: 20 December 2019

The authors wish to correct the following erratum in this paper [1]:

There is a decimal missing in written Formula 1: 0.023 should be 0.0023 . The change was caused by typos and it does not alter the results.

The incorrect Formula (1) is

$$
\mathrm{ETo}=0.023(\mathrm{~T} \text { mean }+17.78) \operatorname{Ro}(\mathrm{T} \max -\mathrm{T} \min ) 0.5
$$

and the correct Formula (1) should be

$$
\mathrm{ETo}=0.0023(\mathrm{~T} \text { mean }+17.78) \text { Ro }(\mathrm{T} \max -\mathrm{T} \min ) 0.5
$$

The authors and editorial office would like to apologize for any inconvenience caused to the readers by these changes. The changes do not affect the scientific results. The manuscript will be updated and the original will remain online on the article webpage.

\section{References}

1. Alvar-Beltrán, J.; Dao, A.; Marta, A.D.; Saturnin, C.; Casini, P.; Sanou, J.; Simone Orlandini, S. Effect of Drought, Nitrogen Fertilization, Temperature and Photoperiodicity on Quinoa Plant Growth and Development in the Sahel. Agronomy 2019, 9, 607. [CrossRef]

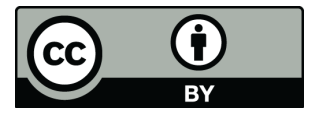

(C) 2019 by the author. Licensee MDPI, Basel, Switzerland. This article is an open access article distributed under the terms and conditions of the Creative Commons Attribution (CC BY) license (http://creativecommons.org/licenses/by/4.0/). 